\title{
Tarsila do Amaral and Glete de Alcântara: history in art and photography
}

\author{
Tarsila do Amaral e Glete de Alcântara: história em arte e fotografia \\ Tarsila do Amaral y Glete de Alcântara: historia en arte y fotografía
}

Rafael Alcantara de Camargo' ORCID: 0000-0003-3252-8515

Luciana Barizon Luchesi' ORCID: 0000-0002-7282-109X

Fernando Porto" ORCID: 0000-0002-2880-724X

Mercedes Neto" ORCID: 0000-0001-7529-9535

Adriana Saturnino Mazziero' ORCID: 0000-0001-8472-8610

Carla Cristina da Cruz Almeida Lima' ORCID: 0000-0001-8898-9455

'Universidade de São Paulo. Ribeirão Preto, São Paulo, Brazil. "Universidade Federal do Estado do Rio de Janeiro. Rio de Janeiro, Rio de Janeiro, Brazil.

How to cite this article: Camargo RA, Luchesi LB, Porto F, Neto M, Mazziero AS, Lima CCCA. Tarsila do Amaral and Glete de Alcântara: history in art and photography.

Rev Bras Enferm. 2020;73(2):e20170839. doi: http://dx.doi.org/10.1590/0034-7167-2017-0839

Corresponding Author: Mercedes Neto

E-mail: mercedesneto.uerj@gmail.com

EDITOR IN CHIEF: Dulce Aparecida Barbosa ASSOCIATE EDITOR: Antonio José de Almeida Filho

Approval: 10-27-2019

\begin{abstract}
Objectives: to analyze the canvas "Retrato de Glete de Alcântara" (freely translated as Portrait of Glete de Alcântara) and discuss the effect of the canvas for Tarsila do Amaral and for Brazilian nursing. Methods: a study in the historical perspective, in the field of visual culture, with analysis in two phases: pre-iconography and iconography. Results: Tarsila do Amaral brings up the woman Glete de Alcântara without the attributes that identify nursing. In this sense, the representation of women on the canvas is a person aligned with the hairstyle of her time, elegantly dressed, with seriousness and haughtiness accentuated by a fixed and directed look. Final considerations: an attempt was made to advance beyond Glete de Alcântara's professional life and her portrayed relationship networks, as well as to approach Tarsila do Amaral's trajectory, beyond the aesthetics and recognition gained.

Descriptors: History; History of Nursing; Photography; Nursing; Art.
\end{abstract}

\section{RESUMO}

Objetivos: analisar a tela "Retrato de Glette de Alcântara" e discutir o efeito da tela para Tarsila do Amaral e para a enfermagem brasileira. Métodos: estudo na perspectiva histórica, no domínio da cultura visual, com análise em duas fases: pré-iconografia e iconografia. Resultados: Tarsila do Amaral traz à baila a mulher Glete de Alcântara, sem os atributos que identificam a enfermagem. Neste sentido, a representação de mulher na tela trata-se de uma pessoa alinhada à moda do penteado de sua época, de traje elegante, com seriedade e altivez acentuada pelo olhar fixo e direcionado. Considerações finais: houve a tentativa de avançar para além da vida profissional de Glete de Alcântara e suas redes de relacionamento da retratada, bem como se aproximar da trajetória de Tarsila do Amaral, para além da estética e o reconhecimento conquistado.

Descritores: História; História da Enfermagem; Fotografia; Enfermagem; Arte.

\section{RESUMEN}

Objetivos: analizar la pantalla "Retrato de Glette de Alcântara" (traducido libremente como Retrato de Glete de Alcântara) y discutir el efecto de la pantalla para Tarsila do Amaral y para la enfermería brasileña. Métodos: estudio en la perspectiva histórica, en el dominio de la cultura visual con análisis en dos fases: pre-iconografía e iconografía. Resultados: Tarsila do Amaral trae a la baila a la mujer Glete de Alcántara, sin los atributos que identifican a la enfermería. En este sentido, la representación de mujer en la pantalla, se trata de una persona alineada a la moda del peinado de su época de traje elegante, con seriedad y altivez acentuada por la mirada fija y dirigida. Consideración finales: se intentó avanzar más allá de la vida profesional de Glete de Alcântara y sus redes de relaciones retratadas, así como acercarse a la trayectoria de Tarsila do Amaral, más allá de la estética y el reconocimiento adquiridos.

Descriptores: Historia; Historia de la Enfermería; Fotografía; Enfermería; Art. 


\section{INTRODUCTION}

The 1960s for the painter Tarsila do Amaral was marked by the simplification of the forms, order and use of blue tones in her works, when she brought Brazilianness from the perspective of visual culture. In the middle of the previous decade, the Neo Pau-Brasil phase of the painter, she began painting on canvas called "Portrait of Glette de Alcântara". The artist, to critics, was considered a pioneer in the reflection of the ecology of the country by the oneiric ${ }^{(1)}$.

For Glete de Alcântara, the 1950s was marked by discussions about the creation of a new Faculty of Medicine at Universidade de São Paulo: Faculdade de Medicina de Ribeirão Preto (1948). It was structured on December 26, 1951, under State Law 1467, especially Article 13, which established the creation of the Escola de Enfermagem de Ribeirão Preto, attached to the Universidade de São Paulo School of Medicine ${ }^{(2)}$.

These are two life trajectories that intersect and lead to the question: what is the reason that led Tarsila do Amaral to represent Glete de Alcântara pictorially? Moreover, justifying the present study could be redundant in the aspect of the importance of the trajectory of the portrayed. But articulating it with the work of art signed by Tarsila do Amaral is the possibility of understanding the decoding of the pictorial representation of Glete de Alcântara and the effect for the Brazilian artist and nursing.

\section{OBJECTIVES}

This study aims to analyze the canvas "Retrato de Glette de Alcântara" (freely translated as Portrait of Glette de Alcântara) and discuss the effect of the canvas for Tarsila do Amaral and for Brazilian nursing.

\section{METHODS}

\section{Ethical aspects}

The research was approved by EERP-USP Research Ethics Committee in February 2013. The image had its use authorized by the artist's heiress, who has the same name as this one and the owners of the canvas.

\section{Theoretical-methodological framework}

For the construction of the historical narrative, documentary sources and adherence literature were used to construct the plot, resulting in the decoding of the canvas by Erwin Panofsky's approach method ${ }^{(3)}$ as pictorial representation.

The term "representation" was adopted in the sense of mimetic evocation by the absence suggested by the presence, in the artist's subjective view, having as its product the representation of the absent by the illusion of the faithful record. In other words, the portrait is not about the flesh-and-blood person, but one of the ways of representing the biological absence, which is the illusion of the real ${ }^{(4-5)}$.

\section{Type of study}

This is a study from the historical perspective, in the field of visual culture.

\section{Methodological procedures}

For the selection of historical sources, we resorted to the physical collections and electronic sites articulated with the adherence literature referring to the life trajectory of the two characters of the story to be narrated, articulated to the history of art. The temporal delimitation was concentrated in the $1950 \mathrm{~s}$ and 1960s, without losing sight of the antecedents, having as justification the period of painting.

\section{Data source}

The data for the construction of the historical narrative came from the recording of the image of the painting entitled "Retrato de Glette de Alcântara" based in the city of Araraquara, state of São Paulo, in the Laura Gimenes de Marqui collection, and in adherence literature for analysis and discussion.

\section{Collection and organization of data}

Data were collected on an electronic website (http://www. base7.com.br/tarsila), in the Catálogo Raisonné de Tarsila do Amaral (freely translated Tarsila do Amaral Raisonné Catalog) (6) in literature documents about the life of Glete de Alcântara in Escola de Enfermagem de Ribeirão Preto's Historical Center, in general files of Universidade de São Paulo, in theses and in the imagetic register of the picture presented in the study.

Data organization occurred by the scale game ${ }^{(7)}$, when the micro context dialogued with the macro and vice versa, by the reduction of the object of study, towards the pictorial representation of the artist, who signed the work on Glete de Alcântara.

\section{Data analysis}

The analysis took place in two phases: pre-iconography and iconography ${ }^{(3)}$. The first was understood as primary, being apparent, natural, of a more basic level as the layer of perception of the work in its pure form. The second was known as secondary or conventional, a level that advances one more step of the analysis and brings the cultural equation and iconographic knowledge, through the analysis matrix adapted for painting ${ }^{(8)}$, for the pictorial representation of the portrayed by the artist. Thus, the analysis, as a result, led to a discussion of the effect of the artist's work on Brazilian nursing.

\section{RESULTS}

The portrait entitled "Retrato de Glette de Alcântara", dating from 1960 , has the dimensions of $64,5 \times 54,5 \mathrm{~cm}$ by Tarsila do Amaral.

The canvas and frame predominate in blue tones - the frame and background of the canvas - highlighting the portrayed in light (dress and skin) and dark (hairstyle) shades, in close-up position with the viewer. The personal attributes displayed are representations of a pair of earrings and double-loop necklace, with pearl reference. The dress is perhaps apart from a canoe-neckline dress, known in French as bateau ${ }^{(9)}$, skirting the transparent lace chest.

The first personal attribute to be treated is the representation of the pearl present on the canvas. It is known from the writings 
that the pearl comes from saltwater/freshwater mollusks, in the presence of an irritating agent that crystallizes calcium carbonate, used to decorate clothing since ancient times. It was potentiated in the nineteenth century, when cultivation for marketing, became visible the use from the 1920s. It had reference to the nineteenth century, when Alexandra Caroline Charllote Louisa Julia - Princess of Wales - dictated fashion at the time when wearing necklace of pearl in line ${ }^{(9-10)}$. This leads to the decoding of elegance, power and prestige.

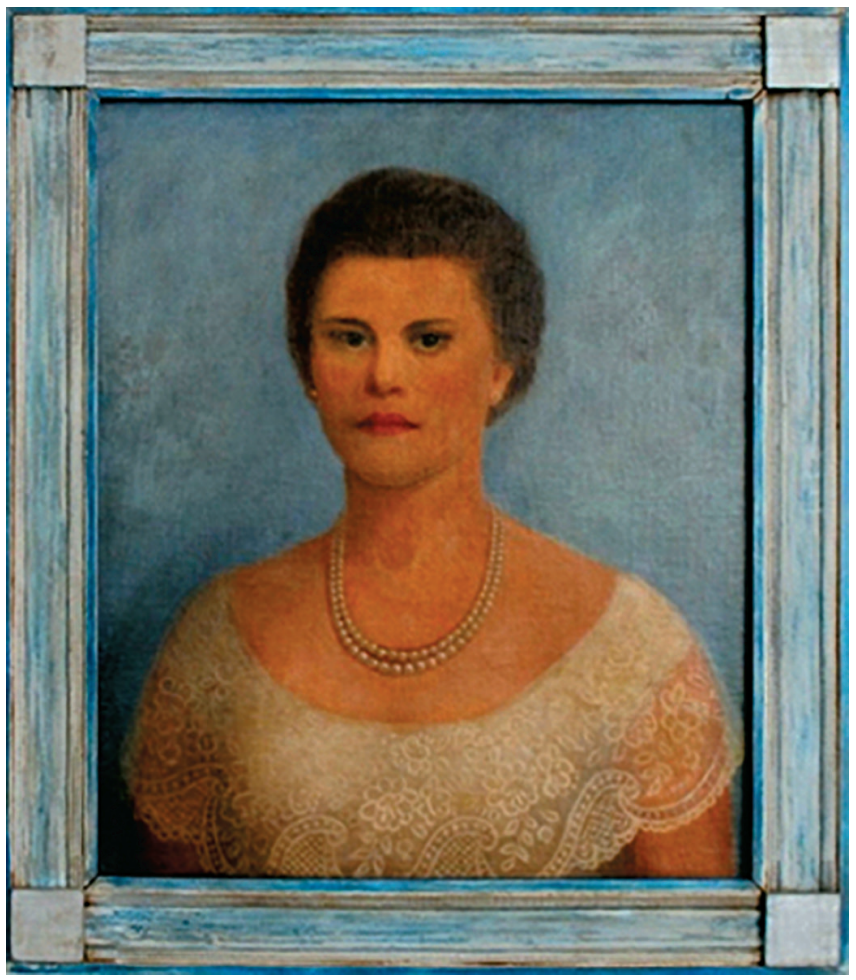

Source: Laura Gimenes de Marqui collection, Araraquara, SP.

Photography: Luciana Barizon Luchesi. Araraquara, 2016.

Figure 1- Retrato de Glette de Alcântara (Tarsila do Amaral-1960)

In the composition of Glete de Alcântara's representation, pearls - in necklace and earrings - are attributes that stand out in the painting. The earrings are points that discreetly enhance the face of the portrayed by offering two small points of light by the brightness of the earring and which serves as a reference for the contour of the face, followed by the proposal of dark hair alignment. The necklace around the neck to the beginning of the chest on the canvas communicates visually with the earrings because it is the same material, offering harmony and balance by filling the chest with light and shadow, subtle, in the pearls' profiled path by size.

The hair, by alignment, follows the trend of straight cut and swing fashion ${ }^{(11)}$. It is known from photographic consultations that Glete de Alcântara had short and slightly wavy hair, which may lead the viewer to the illusion that, for example, it is a bun hairstyle. Even so, the hairstyle is contoured to the physiognomy, resulting in the highlighting of dark-colored eyebrows and eyes, and a reddish nose and lips for the representation of flushed complexions.
The lace reading in the painting is fabric with drawings in hand-made or machine-made openings, common to adorn dresses, veils and shawls ${ }^{(9)}$, which at the same time shows, also hides. It offers lightness and subtle body volume in clothing. This can be visualized by virtue of the illusory transparency of the representation, which is seen in the absence of sleeves in the garment and presence of the arm part complexion.

The lace function, in this type of modeling, can be considered double, that is, of prolonged finishing in the neckline and replacement of the sleeve. Its highlight is the transparency game and the delicate floral pattern in light tones, which adorn the fabric and catch the viewer's attention, especially for those with Victorian repertoire, by referring to the rise of the middle class and the development of industrial capitalism ${ }^{(12)}$.

The gesture of the portrayed, delimited in the representation of the fixed look, refers to the meaning of the mental trigger of understanding who is seen and who sees it. The articulation is done by visual communication and the environment where you can find yourself $f^{(13-14)}$. The portrayed look can, on the one hand, be interpreted as being ready to look and be looked at, as one of the forms of communication - pictorial and spectator representation; another would be as if the representation of her look directly at the viewer to receive it in the visual environment of the canvas; it can also be attributed as if that look were in constant surveillance of the present space; or, as if invited to enter the canvas, in the understanding of a blue-bottomed symbolic portal ${ }^{(15)}$, to know it or even to remember facts and events of connection between the portrayed and the viewer.

Tarsila do Amaral is the author of 10 sculptures, 38 prints, 60 decals, 442 illustrations and illustration studies, 1,319 drawings, studies and annotations, 28 watercolors and gouaches, and 278 paintings, whose canvas by Glete de Alcântara is currently in the Laura Gimenes de Marqui collection. The artist's work goes through 4 phases. The first was called Pau-Brasil until the mid-1920s. The second was titled Anthropophagic in the modernist movement, conceived by her husband at the time, Oswald de Andrade, in 1928. The third phase was the social, and the fourth was called Neo Pau-Brasil, when the works with reference to the landscapes of farms, weddings and processions were dedicated in the $1950 \mathrm{~s}^{(16-17)}$.

In short, through the result of the pre and iconographic analysis of the canvas referring to body hexis, personal attributes and color tones distributed on the canvas, Tarsila do Amaral brings up the woman Glete de Alcântara. This occurs without the attributes that refer to nursing, except for the name known by professionals in the field, as well as some doctors and historians of the craft. In this sense, the representation of women on the canvas is a person who is in line with the style of the hairstyle of her time of elegant dress, with seriousness and haughtiness accentuated by the fixed and directed look.

\section{DISCUSSION}

Glete de Alcântara, born June 24, 1910, in the city of São Sebastião do Paraíso, state of Minas Gerais, studied Nursing in Canada in 1944 and became a professor at Universidade de São Paulo's School of Nursing (EEUSP). She has taught Medical Nursing and Technical Nursing and has furthered her training 
in the United States to obtain the Master of Arts title from the University of Columbia Teacher's College as a Kellog Foundation Fellow. At the time, she also started her second degree in Social Sciences at Universidade de São Paulo, interrupted, but with a degree in $1952^{(18)}$.

In 1952 Glete de Alcântara was hired as Director at Escola de Enfermagem de Ribeirão Preto-USP (EERP-USP), according to the minutes of the $312^{\text {th }}$ Session of the University Council of USP. These minutes were dated March 5, 1952, where the Counselor Dr. Zeferino Vaz thanked Dr. Paulo César de Azevedo Antunes (Director of USP's Faculty of Hygiene and Public Health) for the appointment of Prof. Glete de Alcântara to head the EERP-USP, created in $1951^{(19)}$.

Glete de Alcântara's legacy is broad and extended to the strategies implemented by the privileged position in the political sphere of Brazilian nursing as president of the Associação Brasileira de Enfermagem (Brazilian Nursing Association) (Management 19521954 and 1972-1974) and by virtue of her defense of chair (1963). She was considered the first full-professor nurse in Latin America.

The work under analysis is signed by Tarsila do Amaral (18861973). Born in the city of Capivari, state of São Paulo, daughter of Lydia Dias de Aguiar do Amaral and José Estanislau do Amaral, traditional farmers in the countryside of São Paulo, being educated at home ${ }^{(16)}$. In the early twentieth century she studied in Europe when she produced her first works. She was married to André Teixeira, with whom she had a daughter in 1906. She married other times, being considered a woman ahead of her time in a conservative society ${ }^{(1)}$.

In her artistic career, she met modern art names such as Anita Malfati, Oswald de Andrade, Mario de Andrade, Menotti Del Piecchia. She held exhibitions in Russia, where she gave a lecture on art in Brazil in the 1920s. In 1931 she returned to Brazil when, because of her time in Russia, she was considered a suspect, arrested for a month in the context of latent conflict before the World War II ${ }^{(16)}$.

The 1950s represented her Neo Pau-Brasil phase, but she faced financial difficulties that led her to sell real estate, even in the face of commercialization of her works ${ }^{(16)}$. In this setting of financial difficulties, there is the commission to paint the oil portrait of Glete de Alcântara by her brother Antonio de Alcântara.

Tarsila do Amaral's meeting with Antônio Alcântara is due to the recommendation of Décio de Almeida Prado (1917-2000)(6). He was a theatrical critic, essayist and professor at Universidade de São Paulo's School of Dramatic Art (1948-1963) and married to Ruth Alcântara, sister of Glete de Alcântara ${ }^{(20)}$. Understanding the network of friends of the artist and the person portrayed sheds light on the production of the canvas.

Glete de Alcântara was the eldest daughter of the family with nine brothers - five women and four men. With the death of her mother, she took to herself the education of her younger brothers. This implied the affective relationship with them, despite the record that "her life has tended to the professional side rather than the personal side. Nevertheless, or perhaps for this very reason, the affective dimension occupied a large space in her professional"(21), which did not detract from her brother's affection and appreciation for presenting her with a canvas signed by Tarsila do Amaral.
Another noteworthy fact is the information that Glete de Alcântara would have posed for Tarsila do Amaral at 53 years old ${ }^{(6)}$. However, there is divergence of the data under argument based on the birth year of the one pictured in 1910 and the dating of the 1960 s canvas, so it would be 50 years old. In any case, the 74-year-old artist and the 50-year-old Glete, they wrote at least one page of the history of Brazilian art articulated with that of nursing by the record of the work.

Two inferences can be made from this information: if the production really took place in 1960, it may have been inspired by her brother's wish to give Glete de Alcântara her $50^{\text {th }}$ birthday, which would question the age of 53 mentioned in the catalog. On the other hand, if it were 53 years old, it would mean that the painting would have as its real date 1963, an emblematic year for the professor who defended the first thesis of nursing chair in Latin America and, therefore, the commissioning of the gift. Both information provide important justifications.

The unfolding of the plot for the construction of the historical narrative, in order to reach the effect of the canvas for Tarsila do Amaral and for Brazilian nursing, through the portrayed, is approaching the end. But still, it is up to us to understand the financial difficulty that the artist was going through for the construction of the narrative.

We know that the 1920s and 1930s were of consecration for the artist, although the 1950s was criticized for the alleged exhaustion of her creative ability, due to the rereading of the works of the masters of the past, such as the Girls by Velázquez and the Women of Algiers by Delacroix. To honor and at the same time reevaluate his production of this period, Sérgio Milliet organized the retrospective exhibition of Tarsila do Amaral at Museu de Arte Moderna de São Paulo (São Paulo Museum of Modern Art) ${ }^{(1)}$.

In addition to the criticism suffered and Sergio Milliet's movement to support her, Tarsila suffered from the loss of her granddaughter Beatriz (1949) and her last love, Luís Martins, in the 1950s. This, added to the sale of the farm due to financial difficulties, in the early 1960s, left her a certain emptiness and longing in life with her friends $s^{(17)}$.

Throughout the 1960s, according to the records found, it is promising, as it received new recognition throughout the work, through retrospective exhibitions held at Casa do Artista Plástico; VII São Paulo Biennale; XXXII Venice Biennale; Museu de Arte Moderna do Rio de Janeiro (Rio de Janeiro Museum of Modern Art); and Museu de Arte Contemporânea de São Paulo (São Paulo Museum of Contemporary Art). The last two were considered the most recognized of her career ${ }^{(17)}$.

Décio de Almeida Prado's recommendation to Antônio Alcântara, for the above, shows support for the phase that passed Tarsila do Amaral and the opportunity for him to honor his sister Glete de Alcântara, with a work of the artist for the recognition gained in the past. So we believe this was a good wind for the artist.

To think of the articulation of analysis with discussion is to trace the effect of the canvas for Tarsila do Amaral and Brazilian nursing, through the representation of Glete de Alcântara. There was the opportunity to reflect at first on two personalities who crossed their destinies in the life course.

In this sense, for some unsuspecting viewers of the canvas, it may be the painting of a woman whom Tarsila do Amaral admired 
or was commissioned to her, through the tradition of portraying people, such as Portrait of Fernanda de Castro (1922), Portrait of Mário de Andrade (1922), Portrait of Oswald de Andrade (1922), Portrait of Vera Vicente de Azevedo (1937), Portrait of Mathilde Theresa Franco do Amaral (1957) and the last in the female gender of Glete de Alcântara $(1960)^{(6)}$. For others, the memory of a woman important to nursing for the legacy left, undressed from the representation of the personal attributes of the profession and, for family members, the memory of kinship. For the last two possibilities, the representation leads to longing for family and/or professional life, but it cannot be denied that it is a visual illusion, because even present in pictorial representation, it is absent.

To think at the time, as in present times, to have possession of a canvas signed by Tarsila do Amaral was not about low financial and/or symbolic value by the representativeness that means the work of art, besides seeing it painted on it. That said, we understand that painting adds cultural capital, which results in the power and prestige of two recognized names, each in its own area of activity in the same document, the canvas.

Glete de Alcântara had an interest in culture in general, art, music, literature, among others and when she liked something of that scope, she devoted herself deeply to her study. The author and friend highlights the memory of Tarsila's painting, commissioned by family member, among the works of art present in the professor's house, among other works ${ }^{(22)}$.

Given what has been said, the picture was held by the family for approximately four decades and then for adverse reasons it would not have been seen, when in search of documentation about the portrayed it is found. This should be called the Laura Gimenes de Marqui Collection, because it is part of the Raisonné Tarsila do Amaral Catalog available on the internet, to the delight of admirers of Tarsila do Amaral and Glete de Alcântara.

\section{Study limitations}

In the unfolding of the plot for the construction of the historical narrative on the canvas of the portrayed Glete de Alcântara, we recognize that gaps were left, but they are pertinent and salutary by the study approach. That said, it must be that the historiographical construction does not take place with the end point. It is unfinished because it is likely and continuous when other documentation is found and versions and interpretations can be (re)written to advance the construction of knowledge.

Therefore, believing in the end of the story is a mistake, because as we had the opportunity to read, we still have a lot to know, who was Glete de Alcântara. Investigating their relationships in the professional political field, in the arts, relationships with family members, among many other aspects, is to understand their culture, otherwise it would be the loss of the greatest wealth of the record of your human life.

\section{Contributions to nursing, health or public policy}

The contribution of the study was to highlight, through visual culture, another aspect of the portrayed. It was the possibility to discuss the social and cultural articulation of the Alcântara family, which goes beyond the image and the legacy of the portrayed for the profession. To understand this aspect is to tread the evidence of its achievements, perhaps, previously little articulated in the historiographical investigation.

\section{FINAL CONSIDERATIONS}

This study, like others that try to advance beyond the professional life of a personality, aimed to understand the life trajectory articulated with the portrayal's relationship networks, which are sometimes found underground in memory and documentary collections. Moreover, getting closer to Tarsila do Amaral's trajectory was another opportunity to understand the artist's struggle, with its difficulties, beyond the aesthetics and recognition gained. It was to bathe in the visual culture of art that the writing of history enables and shows what nursing researchers are capable of producing through an imagetic document, with iconographic interpretations about beyond the seen, but for the invisible and within its limitations.

\section{REFERENCES}

1. Amaral AA. Tarsila: sua obra e seu tempo. 3a ed. São Paulo: Edusp; 2003.

2. São Paulo (Estado). Lei n. 1.467 de 26 de dezembro de 1951. Dispõe sobre organização e finalidade da Faculdade de Medicina de Ribeirão Preto, da Universidade de São Paulo. Diário Oficial do Estado de São Paulo, São Paulo (1951 dez 28); Caderno Executivo, p.2-3.

3. Panofsky E. Significado nas artes visuais. 4a ed. São Paulo: Editora Perspectiva; 2011.

4. Ginzburg C. Olhos de Madeira: nove reflexões sobre a distância. São Paulo: Cia. das Letras; 2001.

5. Gombrich EH. Arte e ilusão: um estudo da psicologia da representação pictórica. 4a ed. São Paulo: Martins Fontes; 2007.

6. Base 7 Projetos Culturais, Pinacoteca do Estado de São Paulo. Catálogo Raisonné de Tarsila do Amaral. [Internet]. 1966[cited 2017 Aug 10]. Available in: http://www.base7.com.br/tarsila/

7. Porto F, Neto M, Silva TF, Trigueiro KF, Nassar PR, Neves HA. San Camilo de Léllis: Caridad y bondad en la prestación del cuidado. Rev Cult Cuidados [Internet]. 2017[cited 2017 Aug 10]; 21: 32-42. Available from: https://pesquisa.bvsalud.org/portal/resource/pt/ibc-163340

8. Neto M, Porto F, Nascimento AS. Application of semiotics in the analysis of facsimiles: a documentary research [Internet]. O Braz J Nurs [Internet]. 2002[cited 2017 Aug 10];11(3):848-64. Available in: http://www.objnursing.uff.br/index.php/nursing/article/view/3705/pdf_1

9. Callan GO. Enciclopédia da moda. São Paulo: Companhia das Letras; 2007.

10. Lurie A. A linguagem das roupas. Rio de Janeiro: Rocco; 1997. 
11. Fischer-Mirikin T. Os significados ocultos da roupa feminina: o código de vestir. Rio de Janeiro: Rocco; 2001.

12. Pezzolo DB. Moda e Arte: releitura no processo de criação. São Paulo: Senac; 2013.

13. Belting H. Por uma antropologia das imagens. Rev Concinnitas. 2005;1(8):64-78.

14. White K. 101 Lições a serem aprendidas na escola de artes. São Paulo: WMF Martins Fontes; 2013.

15. Neto M. Aleitamento materno e cuidado nos modos de ver pela janela de Madona Litta de Da Vinci [Tese]. Rio de Janeiro: Universidade Federal do Estado do Rio de Janeiro, Escola de Enfermagem Alfredo Pinto; 2014.

16. Gotlib NB. Tarsila do Amaral: a modernista. 4a ed. São Paulo: Editora Senac; 2012.

17. Brandão A. A mulher, a representação, a arte e a resistência. Os últimos anos de Tarsila do Amaral [Internet]. In: Anais IV fórum de pesquisa científica em arte. 2006; Curitiba, PR, Brasil. Curitiba: Escola de Música e Belas Artes do Paraná. Curitiba; 2006[cited 2017 Aug 10]. p.218-226. Available from: http://www.embap.pr.gov.br/arquivos/File/anais4/angela_brandao.pdf

18. Alcântara G. Memorial. [Concurso para Docência]. São Paulo: Universidade de São Paulo, Faculdade de Medicina de Ribeirão Preto; 1963.

19. Universidade de São Paulo. Conselho Universitário. Ata da 312a sessão (1952 05 mar).

20. Faria JR, Arêas V, Aguiar F. Décio de Almeida Prado: um homem de teatro. São Paulo: Edusp; 1997.

21. Mendes IAC, Leite JL, Leite JL, Trevizan MA. REBEn (Brazilian Journal of Nursing) in the context of the brazilian nursing: the importance of Glete de Alcântara [Internet]. Rev Bras Enferm [Internet]. 2002[cited 2017 Aug 10];55(3):270-4. Available in: http://dx.doi.org/10.1590/ S0034-71672002000300006

22. Rothschild HA. Aspectos culturais e personalidade de Glete de Alcântara. In: Angerami ELS, Pelá NTR. organizadores. Glete de Alcântara: Vida e obra. São Paulo: Rev Tribunais; 1976. p. 29-33. 